\title{
2 A regional perspective of family firms
}

\author{
Evidence from Europe
}

\author{
Rodrigo Basco and Fernanda Ricotta
}

\section{Introduction}

One important characteristic of capitalism, as an economic and political system, is the fact that its productive structure is formed by a large number of private owners who embrace economic activities through small, medium-sized, and large firms. However, there are two questions that require further investigation: (1) who are these owners and (2) how are private owners distributed across geographical space? To a certain extent, capitalism has been recognised as family capitalism because of the high participation of families in businesses, with family businesses representing the most common form of organisation in developed (Adjei, Eriksson, Lindgren, \& Holm, 2019) and emerging economies (Basco, 2018). Family firms dominate national productive structures (Astrachan \& Shanker, 2003; Bjuggren, Johansson, \& Sjögren, 2011) in today's societies. Indeed, they exist in all size categories from micro to large firms (Basco \& Bartkeviciute, 2016), and families own a substantial portion of listed firms around the world (Faccio \& Lang, 2002; La Porta, Lopez-De-Silanes, \& Shleifer, 1999; Martinez-Garcia, Boubakri, Gomez-Anson, \& Basco, 2020). These stylised facts regarding the prevalence of family firms across national contexts have been subjected to an intensive economic history debate (Berghoff, 2006; Burkart, Panunzi, \& Shleifer, 2003; Chandler, 1990) about the benefits and drawbacks of having them embedded in national and regional productive structures.

However, the debate about the prevalence and importance of family firms at the regional level is still in its infancy. The empirical evidence about the regional importance of family firms is contradicting (Stough et al., 2015). Whereas family firms are located in less developed regions in the United States (Chang, Chrisman, Chua, \& Kellermanns, 2008) and in countries with high level of economic entrenchment (Morck \& Yeung, 2004), they are important players in Germany and Italy, usually considered the most industrial countries in Europe (Arrighetti \& Ninni, 2012). For instance, the Italian industrial sector is characterised by a large presence of family firms and, in the German context, small and medium-sized firms (i.e., Mittelstand), most of which are family owned and managed, are the backbone of the regional economy, employing $60 \%$ of all employees subject to social security contributions (BMWi, 2013). 
To continue with the abovementioned debate, this chapter focuses on exploring the prevalence of family firms across European regions. Our findings present a general descriptive picture of their prevalence in industrial productive structures across seven European countries (Austria, France, Germany, Hungary, Italy, Spain, and the United Kingdom). Additionally, we analyse the two-way relationship between family firms and regional context, and while we do not find full support for the argument that family firms are overrepresented in regions with low-quality institutions, we find that the aggregate relationship between family firms and regional competitiveness (i.e., productivity, exports, and innovation) varies across regions within each analysed country.

Our chapter contributes to the endeavour to link the fields of family business and regional studies. In doing so, we attempt to analyse family firms across regions by mapping the prevalence of family firms in European regions. We find that even though family firms are highly prevalent in European regions, they are unevenly distributed. This evidence reveals the importance of further exploring the connection between family firms and the territories in which they dwell. While the family business field has traditionally focused on the relationship between the family and the firm and has failed to contextualise the family business phenomenon (i.e., historical, geographical, and institutional contexts) (Gomez-Mejia, Basco, Müller, \& Gonzalez, 2020), regional studies research has focused on the relationship between the firm and the region and has omitted firms' heterogeneity by considering the specificities of family firms. Therefore, our chapter attempts to recognise family firms as economic actors and to link them to their regional context by presenting empirical evidence that could further motivate new research in the fields of family business and regional studies.

\section{Family firms and European regions}

In this section, we describe the prevalence of family firms in the manufacturing sector across seven European countries: Austria, France, Germany, Hungary, Italy, Spain, and the United Kingdom. We use the EFIGE (European Firms in a Global Economy) dataset, which is a by-product of the European Union project called 'European Firms in a Global Economy: Internal Policies for External Competitiveness'. This dataset contains data from a survey carried out in 2010 that provides comparable cross-country data on approximately 15,000 manufacturing firms in the seven European countries mentioned above. The information in the survey mostly refers to the three-year period of 2007 to 2009 or, in some cases, to 2008 (for a detailed description, see Altomonte and Aquilante [2012]). Survey samples were constructed based on the Bureau van Dijk AMADEUS database. The sampling design was structured with three strata: industry (11 NACE-CLIO industry codes), ${ }^{1}$ region (at the NUTS 1 level of aggregation), and size class (10-19, 20-49, 50-250, more than 250 employees). ${ }^{2}$ Therefore, the EFIGE database is a firm-level dataset of representative samples of manufacturing 
firms (with a lower threshold of 10 employees) across the aforementioned seven European countries (for more information, see Altomonte and Aquilante [2012]). ${ }^{3}$

Our exploratory research focuses on family firm prevalence across 55 NUTS 1 European regions. ${ }^{4}$ The criterion to distinguish family firms from non-family firms is based on respondents' self-perceptions of whether their businesses are family firms (this specific self-perception option has been used in other studies, such as Pongelli, Calabrò, and Basco [2018]). To dig deeper into the analysis, we first provide a descriptive picture of the data by considering the prevalence of family firms in terms of demographic firm characteristics (e.g., firm size and firm age) and family characteristics (e.g., family involvement in ownership and management). Second, we attempt to relate the distribution of family firms across regions by considering the quality of regional institutions. Finally, we close the section by exploring and analysing the prevalence of family firms and its relationship with regional competitiveness (i.e., regional productivity, regional export, and regional innovation).

\section{Descriptive analysis of family firms across European regions}

\section{Prevalence of family firm in the national and regional context}

We begin our exploratory analysis by describing the importance of manufacturing family firms in Austria, France, Germany, Hungary, Italy, Spain, and the United Kingdom. Table 2.1 shows their prevalence in the manufacturing productive structures of these seven European countries. This evidence indicates that the prevalence of family firms is dispersed across national contexts. For instance, the lowest shares of manufacturing family firms are in Hungary (56\%) and France (58\%), while the highest shares are in Germany (84\%) and Austria (82\%). Our first conclusion is that even though family firms are the most important economic actors in European manufacturing productive structures, they are unevenly distributed across European countries. The national disparity in this prevalence could be related to the context in which family firms are born, compete, and die. Future studies

Table 2.1 Percentage of family firms at the national level-manufacturing industry

\begin{tabular}{lc}
\hline Country & Share of family firms (\%) \\
\hline Austria & 82 \\
France & 58 \\
Germany & 84 \\
Hungary & 56 \\
Italy & 76 \\
Spain & 77 \\
United Kingdom & 64 \\
\hline
\end{tabular}




\section{Rodrigo Basco and Fernanda Ricotta}

should further investigate the connection between them and contextual dimensions (for more information, see Basco \& Suwala, 2020; Gomez-Mejia et al., 2020; James et al., 2020; Krueger, Bogers, Labaki, \& Basco, 2020). Beyond the multiple dimensionality of context and level of analysis, we wonder if this uneven distribution persists within each country across regions.

To show the regional distribution of family firms within each of the seven European countries, Figure 2.1 illustrates the regional share of family firms across regions, evidencing that they are not only unevenly distributed across countries but are also unevenly distributed across regions within national

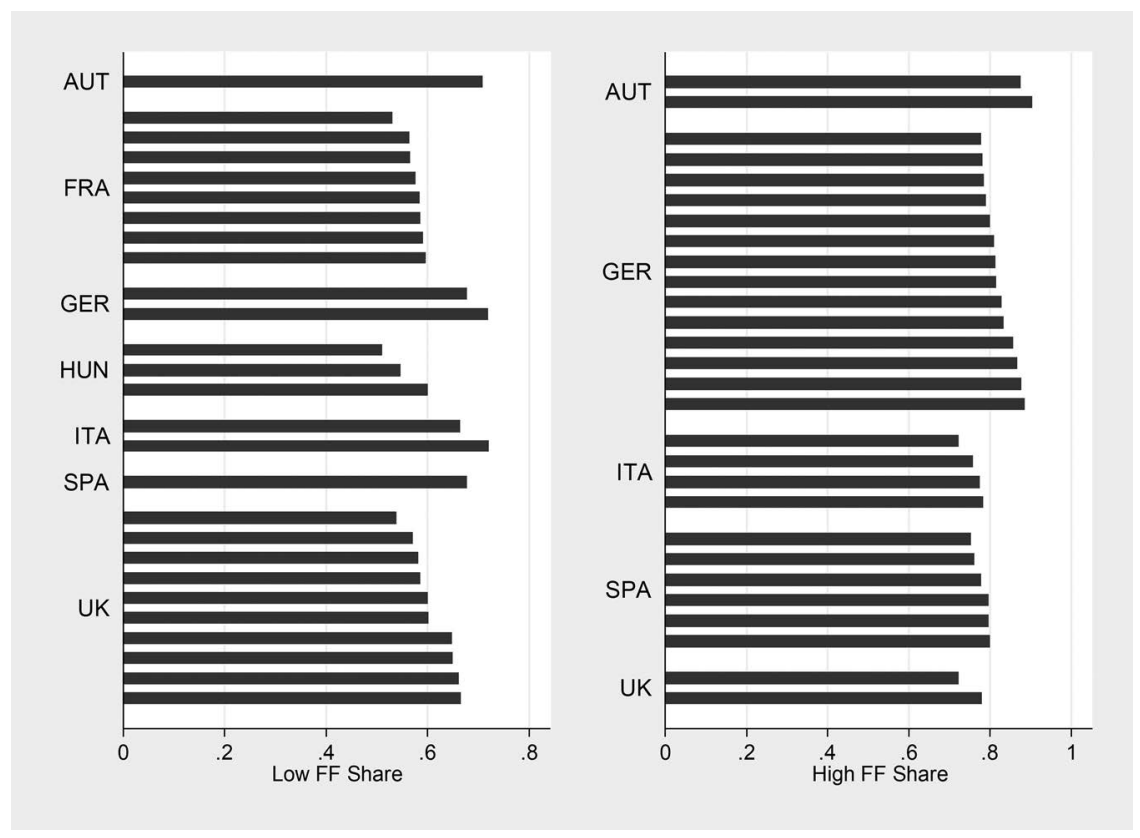

Figure 2.1 Regional share of family firms (under/upper median).

Table 2.2 Regional distribution of family firms across the seven European countries

\begin{tabular}{lccccc}
\hline & Regions & Mean & Std. Dev. & Min. & Max. \\
\hline Austria & 3 & 0.83 & 0.10 & 0.71 & 0.90 \\
France & 8 & 0.57 & 0.02 & 0.53 & 0.60 \\
Germany & 16 & 0.81 & 0.05 & 0.68 & 0.88 \\
Hungary & 3 & 0.55 & 0.04 & 0.51 & 0.60 \\
Italy & 6 & 0.74 & 0.04 & 0.67 & 0.78 \\
Spain & 7 & 0.77 & 0.04 & 0.68 & 0.80 \\
United Kingdom & 12 & 0.63 & 0.07 & 0.54 & 0.78 \\
\hline
\end{tabular}


geographical contexts. For a better interpretation, Table 2.2 contains information about the maximum and minimum values of the regional share of family firms. For instance, the United Kingdom's share of family firms is $64 \%$, but while the lowest regional share is a little more than $50 \%$ in some regions, the highest is almost $80 \%$.

\section{Prevalence of family firms across industrial sectors}

Taking a closer look at the distribution of family firms across industrial sectors, Table 2.3 shows the share of family firms in terms of the analysed European countries and 11 sub-industrial sectors. When taking into account the whole sample, they are highly represented in the sub-industrial sector of 'wood and wood products' but are represented less in the 'coke, refined petroleum products, and nuclear fuel' sector. To explain the differences, we speculate that each country has different competitive advantages in specific industries that attract/ favour family firms. These differences could also be a consequence of specific regional path-dependent processes that cause family firms to have a higher presence in some sectors than others. Finally, the presence of family firms in specific industrial sectors could be a consequence of public policies favouring local business families (political connections). For instance, the share of family firms in the 'chemical and chemical products' sector in Germany - one of the largest in the country, with a long-lasting tradition of families in business - is higher than in France or Hungary. This empirical evidence challenges further research to better understand how national competitive advantages, regional path dependence, and active public policies are linked to the regional prevalence of family firms. Even more, future research should explore how the regional distribution of family firms within each country is linked to particular geographical/territorial characteristics and industries.

Looking at the industrial sectors from a different angle, Table 2.4 shows the share of family firms in terms of the Pavitt sectors by country. When taking into consideration the whole sample, family firms are highly prevalent in traditional industries, as expected, because of the competitive advantages that families may bring to their firms, such as patient capital, family human capital, and social capital, among others. Additionally, the presence of family firms in specialised sectors is also high. On the other hand, the prevalence drops in economies-of-scale sectors, in which family firms seem to have fewer competitive advantages because of the way they finance investments (i.e., based on re-investing profits and avoiding external investors who may jeopardise their control) and manage risk (i.e., more conservative strategies). Additionally, the lower presence of family firms in high-tech sectors seems to confirm the notion that family firms are less prepared to navigate highly dynamic sectors because firms in these sectors may require competitive advantages other than those generated by family involvement. The presence of family firms in high-tech sectors follows a common pattern across the seven European countries. Future research should explore the 


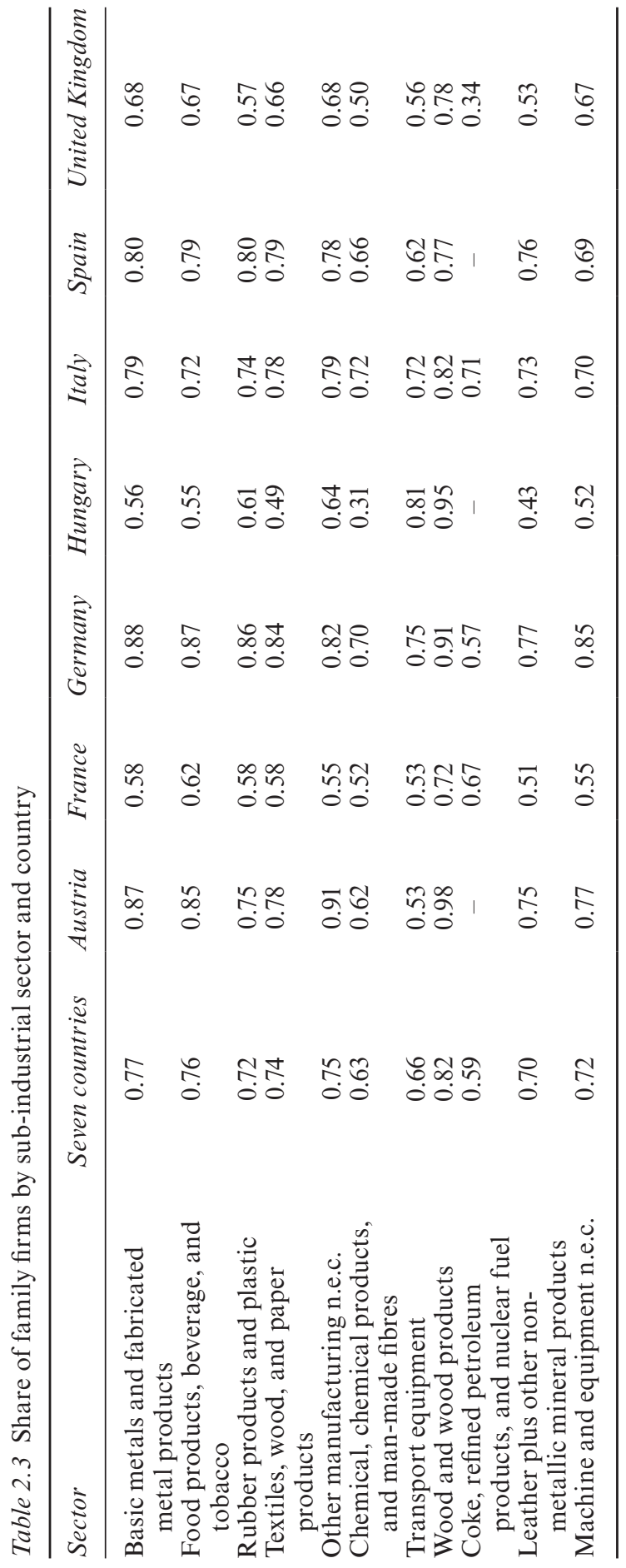


Table 2.4 Share of family firms by Pavitt sector and country

\begin{tabular}{lcccccccc}
\hline $\begin{array}{l}\text { Pavitt } \\
\text { sector }\end{array}$ & $\begin{array}{c}\text { Seven } \\
\text { countries }\end{array}$ & Austria & France & Germany & Hungary & Italy & Spain & $\begin{array}{c}\text { United } \\
\text { Kingdom }\end{array}$ \\
\hline $\begin{array}{l}\text { Economies } \\
\text { of scales }\end{array}$ & 0.69 & 0.72 & 0.52 & 0.79 & 0.49 & 0.74 & 0.70 & 0.59 \\
High tech & 0.67 & 0.68 & 0.50 & 0.76 & 0.25 & 0.64 & 0.77 & 0.45 \\
Specialised & 0.73 & 0.75 & 0.58 & 0.84 & 0.54 & 0.71 & 0.72 & 0.65 \\
Traditional & 0.78 & 0.91 & 0.61 & 0.88 & 0.61 & 0.79 & 0.81 & 0.68 \\
\hline
\end{tabular}

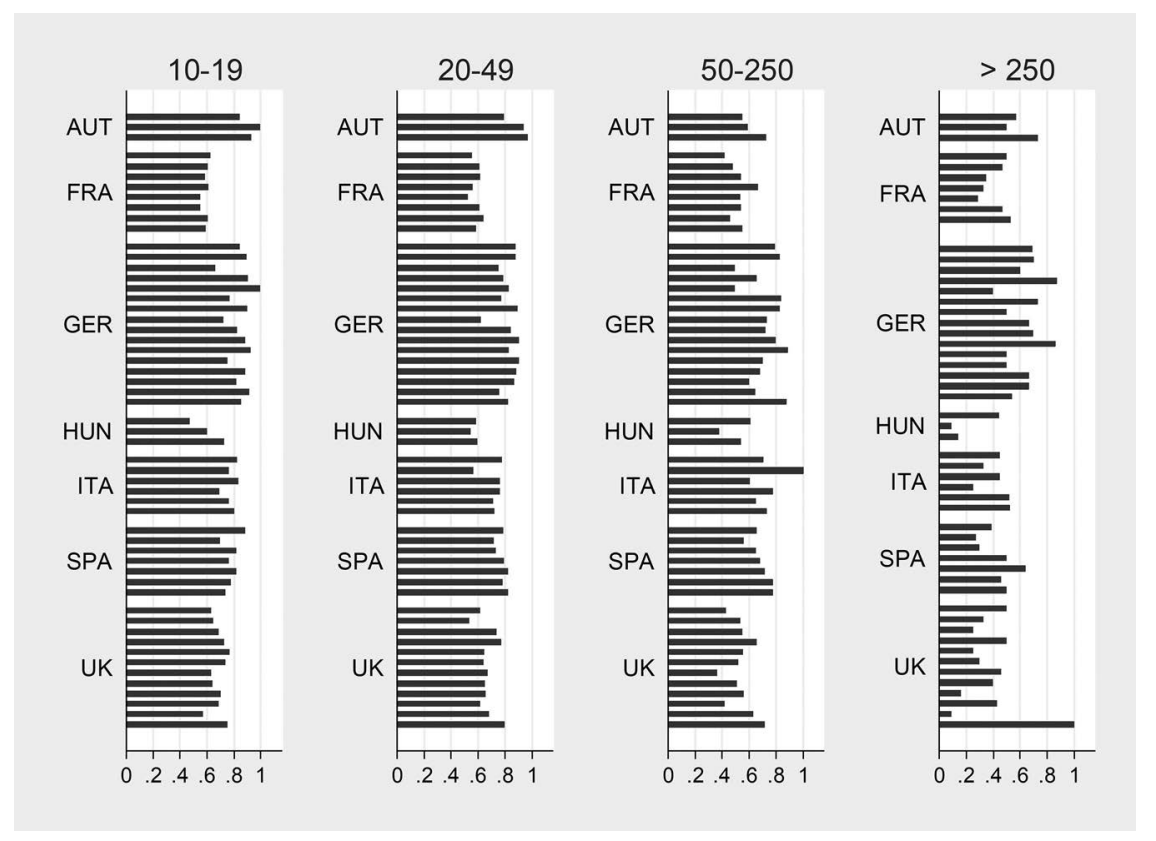

Figure 2.2 Share of family firms by firm size, country, and region.

aforementioned patterns to explain why family firms are highly represented in traditional and specialised sectors, whether they have competitive advantages to operate in these sectors, what these are, and whether these patterns are the consequence of a natural selection process.

\section{Prevalence of family firms based on their demographic characteristics}

Beyond the aforementioned analysis presenting the share of family firms across countries, regions, and industries, an interesting image emerges when analysing their size and age distribution across countries and regions. Family firms are more common in the small and medium-sized firm categories than in the large firm category (see Figure 2.2). However, the share of family 


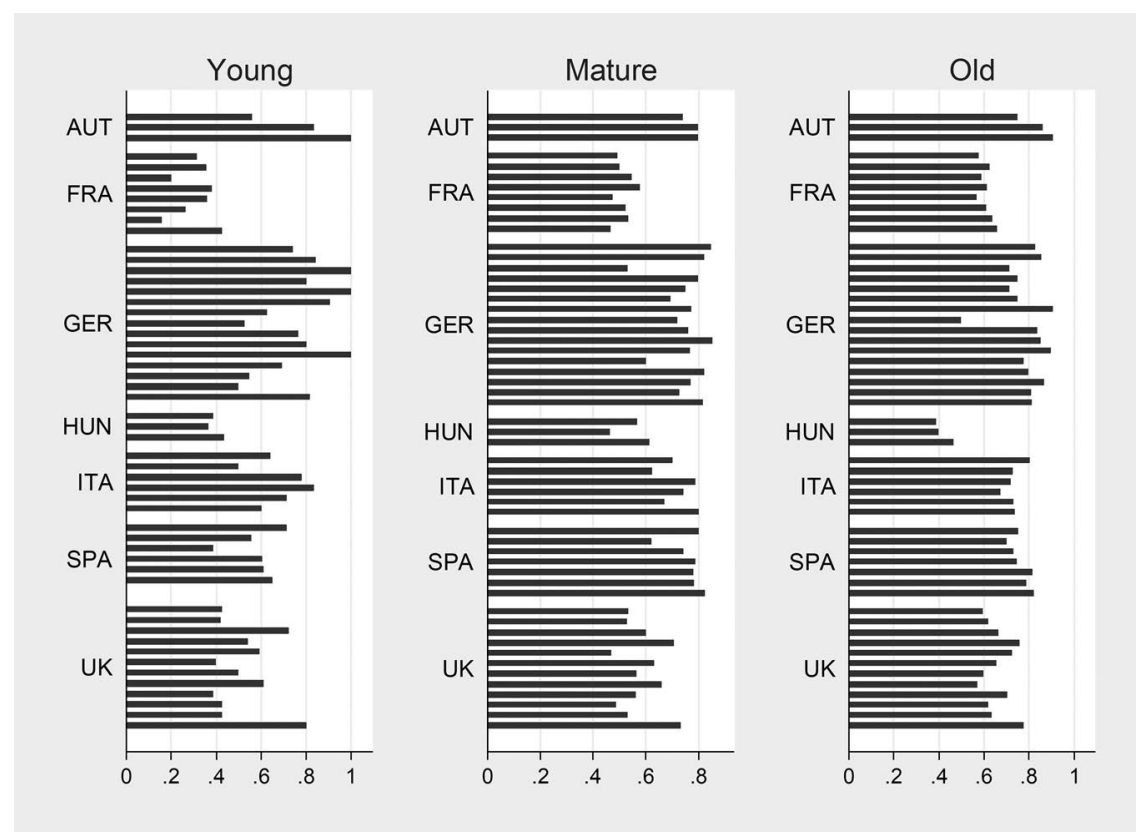

Figure 2.3 Share of family firms by firm age, country, and region.

firms is high in the large firm category in some regions (e.g., in Germany, Austria, and Spain). These findings open the door for further research investigating whether a particular relationship exists between regions and the size of family firms. Regarding firm age, Figure 2.3 shows three firm age classifications: young firms (younger than 6 years old), mature firms (between 6 and 20 years old), and old firm (older than 20 years). Most family firms belong to the mature and old firm categories. However, there is a high dispersion of the share of family firms in terms of age across regions within each country. This descriptive information leads us to call for more research investigating the possible relationships between the age of family firms, the characteristics of regions, and the industries in which family firms dwell.

Finally, we analyse family involvement in the firm, measured as the average number of family managers, across regions in each European country. The aim of this analysis is to visualise whether there is an uneven distribution of family involvement in managerial positions across regions. Table 2.5 shows the extent to which family involvement in managerial positions varies across regions within countries. These differences imply that the level of 'familiness' (i.e., family involvement) of family firms is not the same across regions. For instance, while the dispersion of the average number of family members in German regions is high, ranging from less than $1(.89)$ to almost 4 (3.84) family members, the dispersion of the 
Table 2.5 Average number of family managers in family firms

\begin{tabular}{lccccc}
\hline & Regions & Mean & Std. Dev. & Min. & Max. \\
\hline Austria & 3 & 1.53 & 0.16 & 1.35 & 1.66 \\
France & 8 & 1.67 & 0.21 & 1.46 & 2.13 \\
Germany & 16 & 1.59 & 0.64 & 0.89 & 3.84 \\
Hungary & 3 & 2.58 & 0.59 & 1.94 & 3.1 \\
Italy & 6 & 1.95 & 0.19 & 1.66 & 2.11 \\
Spain & 7 & 2.21 & 0.38 & 1.48 & 2.72 \\
United Kingdom & 12 & 2.15 & 0.19 & 1.81 & 2.47 \\
\hline
\end{tabular}

average number of family members in Austrian regions is low, ranging from 1.35 to 1.66 . This evidence opens the door for future research to explain the possible connection between the degree of familiarity of family firms and regional characteristics.

In sum, from the aforementioned analyses, our main conclusion is that the phenomenon of family firms is unevenly distributed across European regions. This also seems to be related to industrial sector and, to certain extent, to firm characteristics, such as firm size, firm age, and degree of family involvement. The empirical evidence raises two general research questions that may deserve further investigation among family business and regional science scholars: 'Why is the prevalence of family firms unevenly distributed across regions?' and 'Why do family firm characteristics (business related and family related) vary across regions?' In an attempt to address these questions and unveil some preliminary evidence, in the next sub-sections, we explore the relationship between the prevalence of family firms and the quality of regional institutional contexts.

\section{Prevalence of family firms and regional characteristics}

\section{Prevalence of family firms and region size}

Following our intention to visualise patterns underlying the relationship between family firms and regions, Figure 2.4 plots the relationship between the share of family firms and region size, measured by the number of firms in the EFIGE dataset. ${ }^{5}$ The majority of UK and German regions are concentrated in the quadrants representing a below-average share of family firms and a below-average number of regional firms. For Germany, only three regions have an above-average share of family firms and an above-average number of regional firms. Four of the six Italian regions have the same characteristics. French regions have a low share of family firms, but the majority of them are larger than average. This preliminary evidence opens the door for further investigations of the relationship between family firm prevalence and regional characteristics, specifically in terms of external agglomeration. 


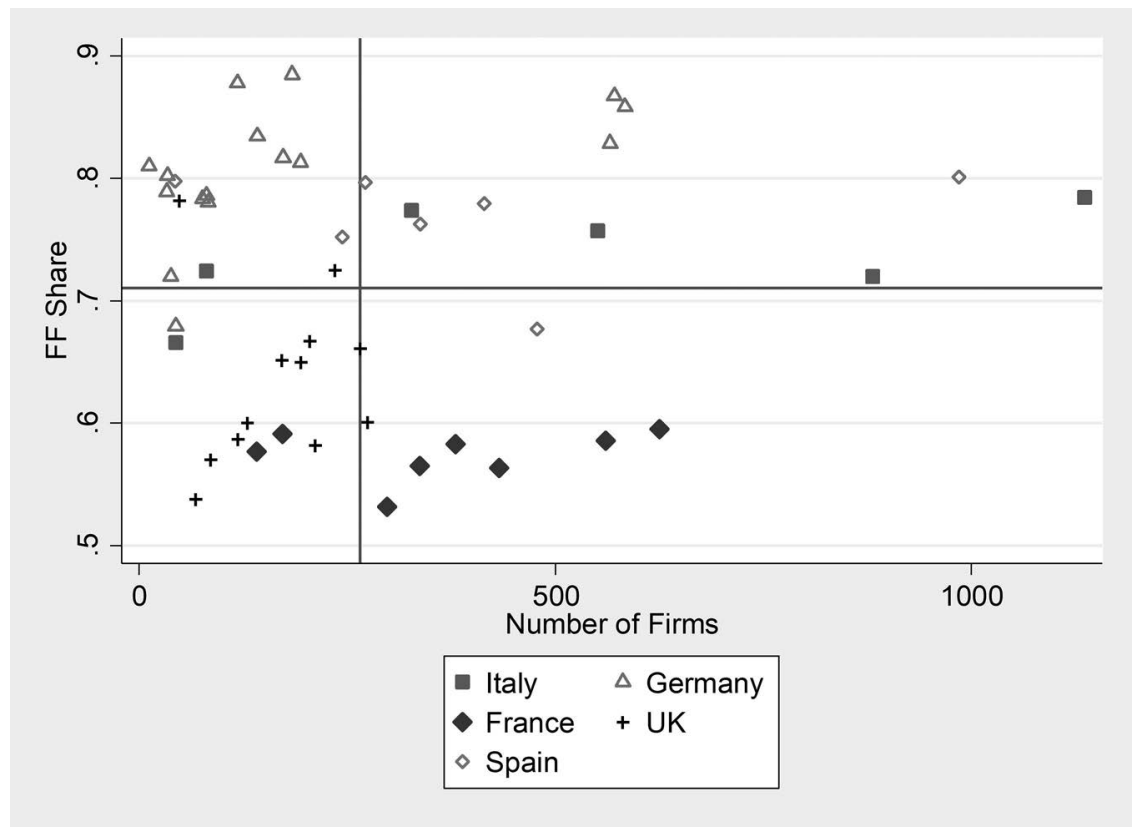

Figure 2.4 Relationship between share of family firms and region size (proxied by total number of firms using the EFIGE dataset).

Note: $y=0.70+0.0003 x(p$-value $=0.63)$.

\section{Quality of regional institutions and prevalence of family firms}

The current debate in the academic sphere is whether there is a relationship between the presence of family firms and the quality of institutional contexts. The most well-known hypothesis, at least in explaining the prevalence of family firms in developing countries (Khanna \& Palepu, 2000), is that the presence of family firms is higher in low-quality institutional contexts because families and their economic and social networks are able to fill institutional voids. To test whether there is an association between the quality of institutions and the presence of family firms in European regions, we use Charron, Dijkstra, and Lapuente's (2014) European 'quality of government' indicator (EQI) calculated at the regional level. This indicator is based on responses to a survey aimed at capturing average citizens' perceptions of and experiences with corruption and the extent to which they rate public services provided by local authorities as impartial and of good quality. In Figure 2.5, we use the scores of the three pillars that comprise this indicator-namely, corruption, impartiality, and quality (for more information, see Charron et al., 2014).

When we correlate the regional share of family firms and the quality of regional institutions in the European context, we observe contradicting results that both support and reject the argument linking family firms and 
(a)

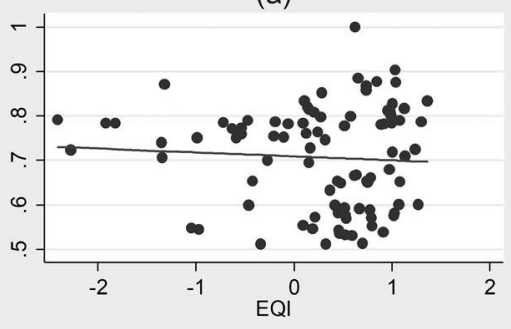

(c)

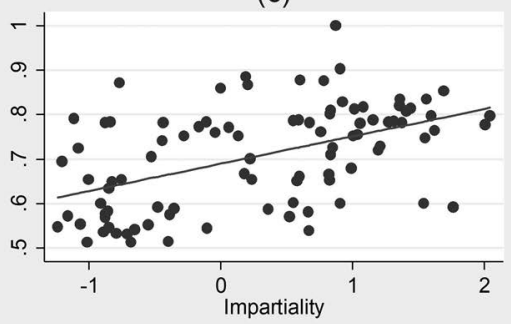

(b)

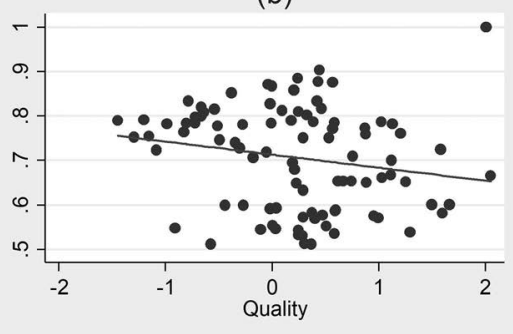

(d)

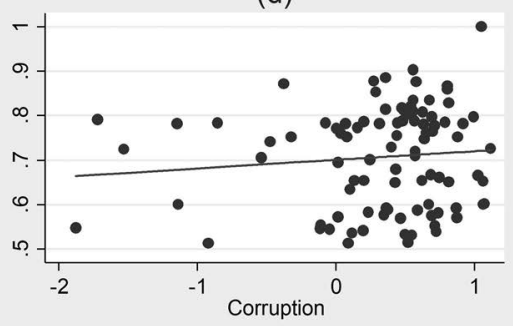

Figure 2.5 Relationship between share of family firms and EQI.

Note: Panel a: $y=0.71-0.009 x(p$-value $=0.55)$; Panel b: $y=0.71-0.029 x(p$-value $=0.06)$; Panel c: $y=0.69+0.061 x(p$-value $=0.00)$; Panel d: $y=0.70-0.019 x(p$-value $=0.33)$.

low-quality institutional contexts. While Panel a in Figure 2.5 shows that there is no association between the quality of government index and the prevalence of family firms, the analysis considering each dimension comprising the quality of government index shows differences. There is negative relationship between the quality dimension and the regional share of family firms (Panel b in Figure 2.5). This means that the lower the quality of services, the higher the percentage of family firms in the region, supporting the argument that family firms may replace formal institutions. However, the dimension of impartiality (i.e., the impartiality of institutions that exercise government authority) has a positive association with the regional share of family firms (Panel c in Figure 2.5). This means that the higher the impartiality, the higher the percentage of family firms in the region, which goes against the previous argument. For the last dimension, corruption, we do not find any association (Panel $\mathrm{d}$ in Figure 2.5). This preliminary evidence indicates that the prevalence of family firms in regions is complex and requires further attention. If formal institutions create conditions for individuals to exploit economic opportunities and incentives to use specific business forms (i.e., family firms), we wonder-and future studies should further investigate-what combinations of formal institutional dimensions favour family firms and other types of organisational forms. 


\section{Family firms and regional competitiveness across European regions}

In this sub-section, following recommendations from Stough et al (2015), we focus on the aggregate effect of family firms across European regions on regional competitiveness in terms of productivity, exports, and innovation. While we implicitly argued in the previous sections that the family firm phenomenon is a consequence of regional context, in this section, we unveil an alternative contribution of family firms for regional development - namely, the economic and social impacts of having high- or low-level family firm prevalence. In other words, we wonder if the aggregate presence of family firms affects regional competitiveness.

\section{Regional productivity}

Taking the whole sample, it looks like there is no relationship between regional total factor productivity (TFP) and the share of family firms. ${ }^{6}$ As we can see in Figure 2.6, German regions are mainly positioned in the top-right quadrant, characterised by a high share of family firms and high regional TFP. On the contrary, French and UK regions are positioned in the lower-left quadrant characterised by a low share of family firms and low regional TFP. Finally, Italian and Spanish regions share a similar pattern: most of their regions are positioned in the lower-right quadrant characterised by a high

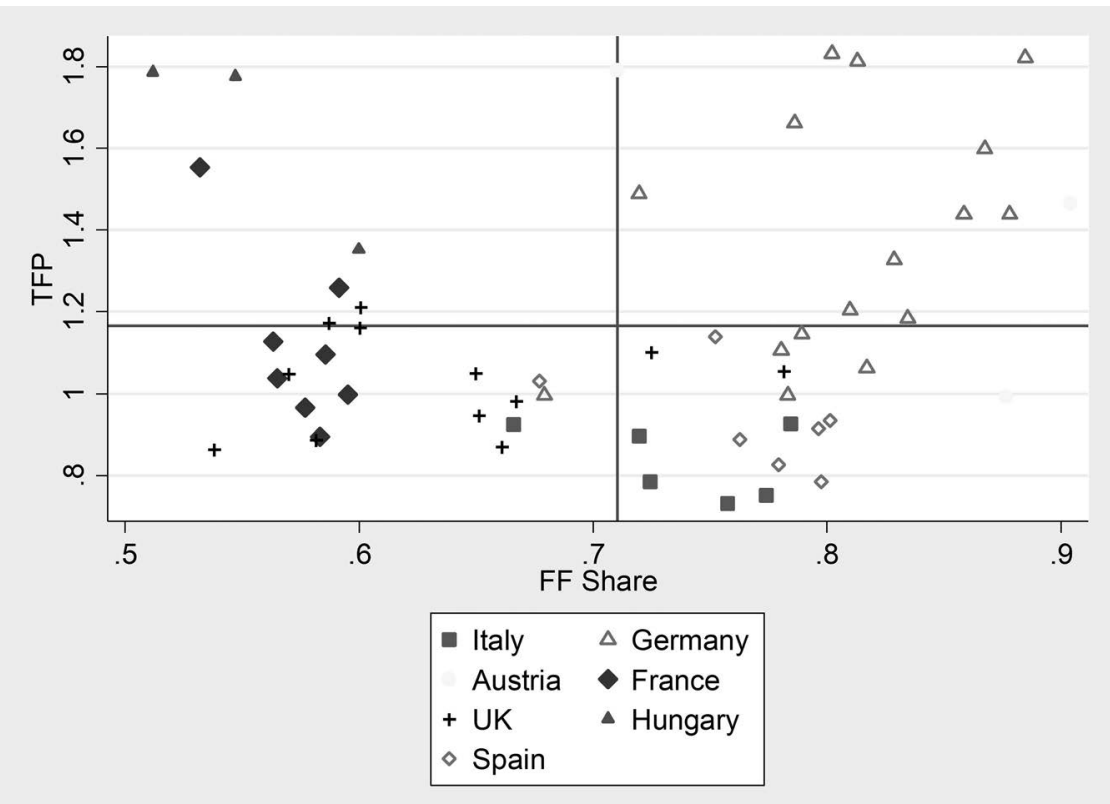

Figure 2.6 Relationship between share of family firms and TFP by region. Note: $y=0.66+0.041 x(p$-value $=0.396)$. 
share of family firms and low regional TFP. Based on this preliminary findings, future studies should deeply explore whether, when, and how family firms contribute to regional productivity.

\section{Regional exports}

Our analysis shows that there is no relationship between the share of regional exporters and the prevalence of family firms across European regions. ${ }^{7}$ Only in the UK context does the relationship seem to be positive-that is, the higher the presence of family firms, the higher the exporters in the region. Even though it is widely recognised that exports and productivity are generally correlated at the firm level (i.e., the most productive firms are more likely to become exporters), we wonder if this effect can be extrapolated to the regional level. As shown in Figure 2.7, the majority of German regions are in the quadrant characterised by a high share of family firms and a below-average share of exporters, while three out of the six Italian regions are in the quadrant characterised by a high share of family firms and a high share of exporters. In this sense, further studies should investigate the possible connection between regional exports and productivity and the regional prevalence of family firms.

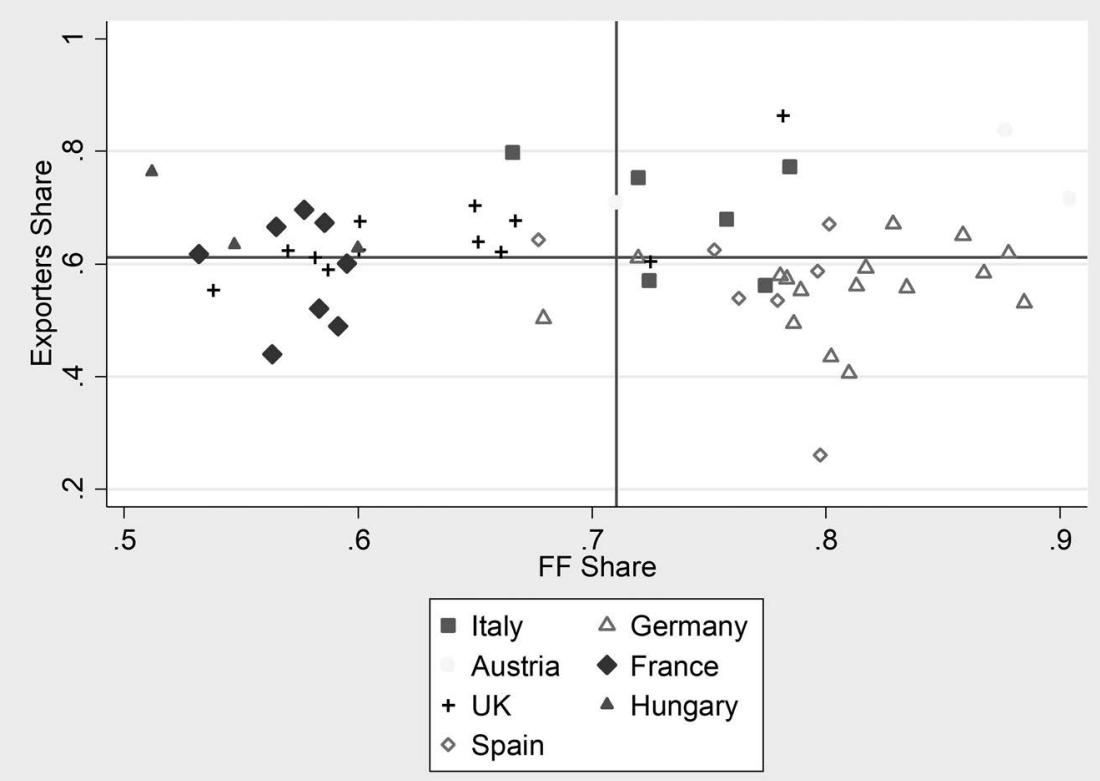

Figure 2.7 Relationship between regional share of family firms and regional exporters.

Note: $y=0.662-0.069 x(p$-value $=0.598)$. 


\section{Regional innovation}

There seems to be a slightly positive relationship between the share of family firms and regional innovation. ${ }^{8}$ The majority of German regions are located on the right side of Figure 2.8, indicating a high share of family firms, but these areas have near- or below-average regional innovators (calculated for all European regions). In the case of Italian regions, four out of six are characterised by both a high share of family firms and above-average regional innovators. This preliminary evidence opens the door for future research exploring the relationship between innovation and tradition in family business and its contribution to regional innovation systems.

\section{Combining family firm exporters and innovative behaviour across regions}

Focusing on family firms, we classify regions in terms of family firms' exporting and innovation activities. Indeed, Figure 2.9 combines the measures of regional family firm exporters and innovators, ${ }^{9}$ forming four quadrants: less dynamic regions, exporter regions, dynamic regions, and innovator regions. ${ }^{10}$ Most Italian and Austrian regions fall into the dynamic quadrant in which the share of family firm exporters and innovators is high. In contrast,

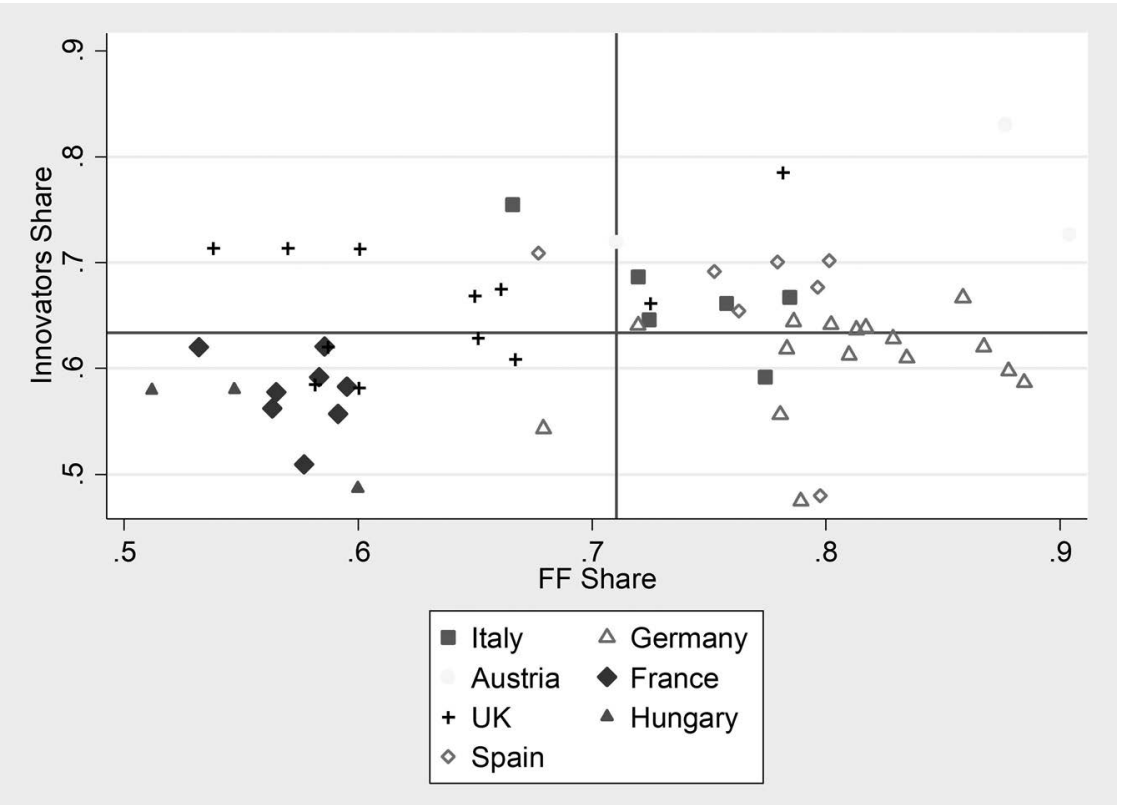

Figure 2.8 Relationship between regional share of family firms and regional innovators.

Note: $y=0.524+0.154 x(p$-value $=0.081)$. 


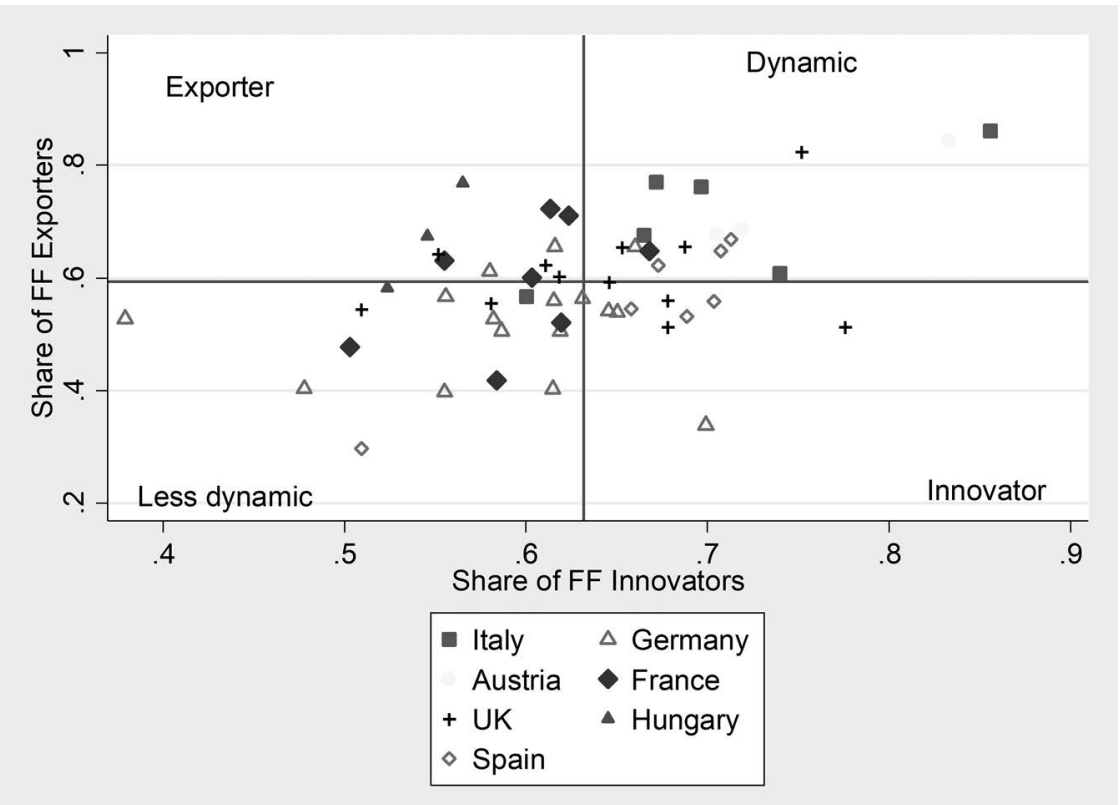

Figure 2.9 Regional share of family firms combining innovators and exporters. Note: $y=0.167+0.675 x(p$-value $=0)$.

most German regions fall into or are close to the quadrant characterised by less dynamic regions in which the share of family firm exporters and innovators is low. The preliminary finding for Germany may require further research because of the importance of family firms as the backbone of innovation and internationalisation in German regions. However, this general perception may be based on only a few firms, so the same pattern may not necessarily hold for other family firms that form the regional productive structure. French regions follow a similar pattern to that of German ones, and Spanish regions are distributed between dynamic and innovator regions.

\section{The case of Italy}

To further explore the prevalence and importance of family firms across regions, in this section, we focus our analysis on the Italian context. Italy is an interesting case study for two main reasons. First, it has high geographical heterogeneity in economic conditions that has created large and persistent disparity between the south and the rest of the country (Iuzzolino, Pellegrini, \& Viesti, 2011). Second, the backbone of its productive system is characterised by a large number of small and medium enterprises (SMEs) 
that are often organised within industrial districts and by the progressive disappearance of large firms in strategic sectors (Amatori, Bugamelli, \& Colli, 2011). A large portion of these SMEs are run as family businesses or have family shareholders present who are able to influence company decisions (Cucculelli \& Micucci, 2008).

Data for our analysis come from the $\mathrm{X}^{\text {th }}$ UniCredit-Capitalia survey (2008), which covers the period 2004-2006 and was compiled using information collected through a questionnaire sent to a representative sample of Italian manufacturing firms. While the survey covers the universe of manufacturing firms in Italy with more than 500 employees, it uses a representative sample of manufacturing companies with 10-500 employees considering three strata: four geographical areas, four Pavitt sectors, and five firm size classes. ${ }^{11}$

Following the structure we used in the previous section, we start the analysis with a descriptive view of the prevalence of family firms across Italian geographical areas and regions. ${ }^{12}$ For the sake of completeness, in the tables, we leave regions with few firms, such as Calabria, Basilicata, and Molise. ${ }^{13}$ For these regions, the results are only representative of the firms reported in the sample. Additionally, we focus on family firm prevalence by considering business and family characteristics, such as industry, firm size, firm age, and family involvement at the firm level. Second, we analyse the relationship between the prevalence of family firms and the quality of regional institutions. Finally, we reveal the importance of family firms in terms of regional productivity, regional exports, and regional innovation.

\section{Descriptive analysis of family firms across Italian regions}

In this descriptive analysis, a firm is considered to be a family firm if the respondent declared in the UniCredit-Capitalia questionnaire that the company is controlled or owned by an individual or a family. The average share of family firms in Italy is $66 \%$. The four geographical areas (northeast, northwest, centre, and south) have a similar average share of family firms, ranging from $65 \%$ for the northeast to $68 \%$ for the south. All Italian regions have a high presence of family firms, and the share of family firms across regions varies from approximately $50 \%$ in the region of Sardegna to more than $70 \%$ in Sicilia (see Table 2.6). These findings confirm our argument in the previous section that family firms are unevenly distributed across regions.

\section{Prevalence of family firm across industries}

The prevalence of family firms across sectors is high in almost all subsectors except for 'coke, refined petroleum products, and nuclear fuel', for 
Table 2.6 Share of family firms across Italian regions

\begin{tabular}{lrc}
\hline Region & Number offirms & Share of family firms \\
\hline Emilia Romagna & 578 & 0.61 \\
Friuli Venezia Giulia & 140 & 0.67 \\
Trentino Alto Adige & 66 & 0.59 \\
Veneto & 610 & 0.65 \\
Northeast & 1,394 & 0.65 \\
Liguria & 50 & 0.54 \\
Lombardia & 1,533 & 0.68 \\
Piemonte & 490 & 0.64 \\
Valle D'Aosta & 6 & 0.74 \\
Northwest & 2,079 & 0.66 \\
Lazio & 121 & 0.70 \\
Marche & 194 & 0.67 \\
Toscana & 387 & 0.62 \\
Umbria & 77 & 0.66 \\
Centre & 779 & 0.65 \\
Abruzzo & 108 & 0.64 \\
Basilicata & 12 & 0.81 \\
Calabria & 29 & 0.82 \\
Campania & 152 & 0.69 \\
Molise & 11 & 0.55 \\
Puglia & 119 & 0.70 \\
Sardegna & 55 & 0.55 \\
Sicilia & 70 & 0.74 \\
South & 556 & 0.68 \\
Italy & 4,808 & \\
Mean (*) & & 0.66 \\
Std. Dev. (*) & & 0.08 \\
Min. (*) & & 0.53 \\
Max. (*) & & 0.83 \\
(2) & & \\
\hline
\end{tabular}

(*) Statistics calculated considering regional values for the share of family firms.

which the percentage is less than $50 \%$ (see Table 2.7). The distribution of the share of family firms oscillates between $57 \%$ for 'medical, precision and optical instruments, watches and clocks' and $76 \%$ for 'office machinery and computers'. In terms of Pavitt sectors, the prevalence of family firms is evenly distributed across traditional, high-tech, specialised, and economies-of-scale sectors (Table 2.8). However, when looking at the share of family firms across sectors and regions, we observe that in the northwest, they are highly represented in traditional sector, whereas in the south, they are highly represented in the high-tech sector. However, it is worth noting that only 13 firms in the south are in the high-tech sector. These results for Italy challenge what we found in the previous section when analysing all seven European regions. It seems that the relationship between family firms and industries requires further research. 


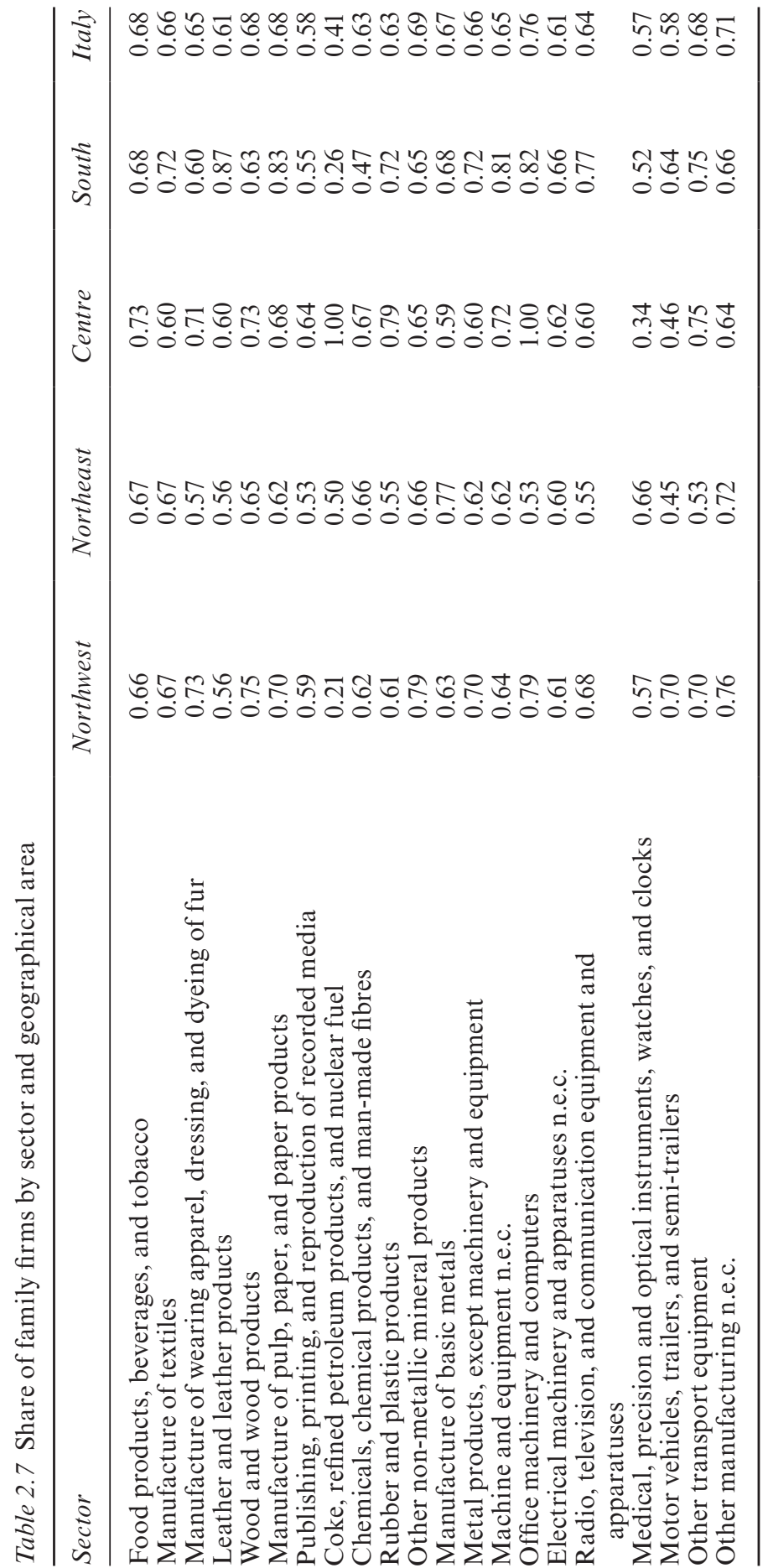


Table 2.8 Share of family firms by Pavitt sector and geographical area

\begin{tabular}{lccccc}
\hline Pavitt sector & Northwest & Northeast & Centre & South & Italy \\
\hline Traditional & 0.69 & 0.63 & 0.65 & 0.69 & 0.66 \\
High tech & 0.62 & 0.61 & 0.66 & 0.82 & 0.64 \\
Specialised & 0.64 & 0.61 & 0.65 & 0.71 & 0.64 \\
Economies of & 0.64 & 0.69 & 0.66 & 0.62 & 0.66 \\
$\quad$ scale & & & & & \\
\hline
\end{tabular}

Table 2.9 Share of family firms across firm size categories and Italian regions

\begin{tabular}{lcccc}
\hline Region & \multicolumn{4}{c}{ Firm size categories } \\
\cline { 2 - 5 } & $\begin{array}{l}\text { 11-20 } \\
\text { employees }\end{array}$ & $\begin{array}{l}\text { 21-50 } \\
\text { employees }\end{array}$ & $\begin{array}{l}\text { 51-250 } \\
\text { employees }\end{array}$ & $\begin{array}{l}\text { More } \\
\text { than 250 }\end{array}$ \\
\hline Emilia Romagna & 0.64 & 0.58 & 0.59 & 0.61 \\
Friuli Venezia Giulia & 0.61 & 0.77 & 0.62 & 0.70 \\
Trentino Alto & 0.67 & 0.55 & 0.52 & 0.54 \\
$\quad$ Adige & & & & \\
Veneto & 0.68 & 0.67 & 0.59 & 0.59 \\
Northeast & 0.65 & 0.64 & 0.59 & 0.61 \\
Liguria & 0.45 & 0.66 & 0.46 & 0.70 \\
Lombardia & 0.69 & 0.68 & 0.67 & 0.49 \\
Piemonte & 0.68 & 0.63 & 0.63 & 0.50 \\
Northwest & 0.68 & 0.67 & 0.66 & 0.49 \\
Lazio & 0.77 & 0.64 & 0.73 & 0.68 \\
Marche & 0.71 & 0.61 & 0.69 & 0.67 \\
Toscana & 0.61 & 0.62 & 0.70 & 0.30 \\
Umbria & 0.82 & 0.63 & 0.51 & 0.58 \\
Centre & 0.67 & 0.62 & 0.68 & 0.58 \\
Abruzzo & 0.66 & 0.62 & 0.65 & 0.51 \\
Basilicata & 0.76 & 0.75 & 1.00 & - \\
Calabria & 0.80 & 0.86 & 0.82 & - \\
Campania & 0.68 & 0.77 & 0.61 & 0.37 \\
Molise & 0.45 & 0.50 & 0.67 & 0.00 \\
Puglia & 0.68 & 0.76 & 0.59 & 0.61 \\
Sardegna & 0.55 & 0.58 & 0.50 & 0.47 \\
Sicilia & 0.65 & 0.79 & 0.81 & - \\
South & 0.67 & 0.73 & 0.65 & 0.47 \\
\hline
\end{tabular}

\section{Prevalence of family firms based on their demographic characteristics}

Regarding the share of family firms considering the size of firms across Italian regions, the empirical evidence shows mixed results (Table 2.9). Looking at the different geographical areas, in the northeast, the presence of family firms is similar across all three firm size categories; however, in the remaining geographical areas, their prevalence in the large firm category is lower than in the other size categories. Focusing on regions, there are regions in 
which the prevalence of family firms is lower in the medium and large firm categories than in the small firm category, such as in Campania and Umbria, and there are other regions in which the prevalence remains stable across all three firm size categories, such as in Emilia Romagna. Even though these results may partially support the general belief that family firms are more prevalent in the small and medium firm categories, this is not the case in all regions. It is important to highlight that Emilia Romagna is well known for hosting clusters of firms related to mechanical engineering, automotive manufacturing, and agrifood. Thus, one could assume that there might be a relationship between family firm prevalence and external localisation economies that could be explored further. Future studies should thus investigate what regional mechanisms can explain the uneven/even regional distribution of family firms across different size categories.

When considering family firm prevalence across age categories (Table 2.10 ) in the Italian regional context, we also observe that family firms tend to belong to the mature (between six to 20 years old) and old (more than 20 years old) firm age categories. This result may support the argument that with time, firms become family firms by incorporating family members and by developing founders' intention to transfer ownership and/or management to upcoming generations. In general, the percentage of family firms in the new firm category (less than 6 years old) is lower than in the other categories

Table 2.10 Share of family firms across firm age categories and regions

\begin{tabular}{lccc}
\hline Region & $\begin{array}{c}\text { Less than 6 years } \\
\text { (young) }\end{array}$ & $\begin{array}{c}\text { Between 6 and 20 } \\
\text { years (mature) }\end{array}$ & $\begin{array}{c}\text { More than 20 } \\
\text { years (old) }\end{array}$ \\
\hline Emilia Romagna & 0.51 & 0.58 & 0.63 \\
Friuli Venezia Giulia & 0.60 & 0.70 & 0.67 \\
Trentino Alto Adige & 0.32 & 0.65 & 0.63 \\
Veneto & 0.59 & 0.64 & 0.67 \\
Northeast & 0.54 & 0.62 & 0.66 \\
Liguria & 0.00 & 0.45 & 0.64 \\
Lombardia & 0.52 & 0.67 & 0.70 \\
Piemonte & 0.54 & 0.55 & 0.69 \\
Northwest & 0.52 & 0.63 & 0.69 \\
Lazio & 0.32 & 0.71 & 0.79 \\
Marche & 1.00 & 0.59 & 0.67 \\
Toscana & 0.57 & 0.61 & 0.64 \\
Umbria & 0.33 & 0.57 & 0.75 \\
Centre & 0.60 & 0.62 & 0.68 \\
Abruzzo & 0.64 & 0.69 & 0.54 \\
Basilicata & - & 0.70 & 0.83 \\
Calabria & 1.00 & 0.68 & 0.88 \\
Campania & 0.77 & 0.88 & 0.69 \\
Molise & - & 0.73 & 0.14 \\
Puglia & 0.94 & 0.64 & 0.59 \\
Sardegna & 0.37 & 0.79 & 0.50 \\
Sicilia & 0.72 & 0.71 & 0.69 \\
South & 0.76 & & 0.63 \\
& & & \\
\hline & & &
\end{tabular}


Table 2.11 Family involvement across Italian regions (average number of family managers)

\begin{tabular}{lc}
\hline Region & Family managers \\
\hline Emilia Romagna & 1.85 \\
Friuli Venezia Giulia & 2.34 \\
Trentino Alto Adige & 1.52 \\
Veneto & 1.59 \\
Northeast & 1.77 \\
Liguria & 4.84 \\
Lombardia & 2.08 \\
Piemonte & 1.39 \\
Northwest & 1.98 \\
Lazio & 1.87 \\
Marche & 1.21 \\
Toscana & 1.84 \\
Umbria & 1.35 \\
Centre & 1.64 \\
Abruzzo & 1.61 \\
Basilicata & - \\
Calabria & 0.92 \\
Campania & 1.63 \\
Molise & 1.25 \\
Puglia & 1.27 \\
Sardegna & 1.31 \\
Sicilia & 0.97 \\
South & 1.35 \\
\hline
\end{tabular}

across almost all Italian regions (with some exceptions, such as Campania and Puglia). It is important to highlight the high presence of young family firms in regions located in the south. This geographical area has the highest share of young family firms. One reason for this high prevalence of young family firms could be the incentives provided in this part of the country for new start-up firms. Further research should investigate the phenomenon of entrepreneurial families that seems to have emerged in the south of Italy in contrast with the presence of mature family firms in the north of Italy and the consequences for future regional economic and social development.

Finally, Table 2.11 shows the familiarity of family firms (measured as the average number of family managers) across Italian regions. There are regions with an average of two family managers or higher, such as in Friuli Venezia Giulia and Liguria, while regions in the south all have an average number of family managers lower than the national mean (1.78). As expected due to the higher presence of mature and old family firms, in the north of Italy we have more family members involved than family firms in the south.

\section{Prevalence of family firms and quality of Italian regional institutions}

Following the aim to relate the prevalence of family firms and the quality of institutions for the Italian sample, we use Golden and Picci's (2005) corruption indicator as a proxy for the quality of regional institutions. This 


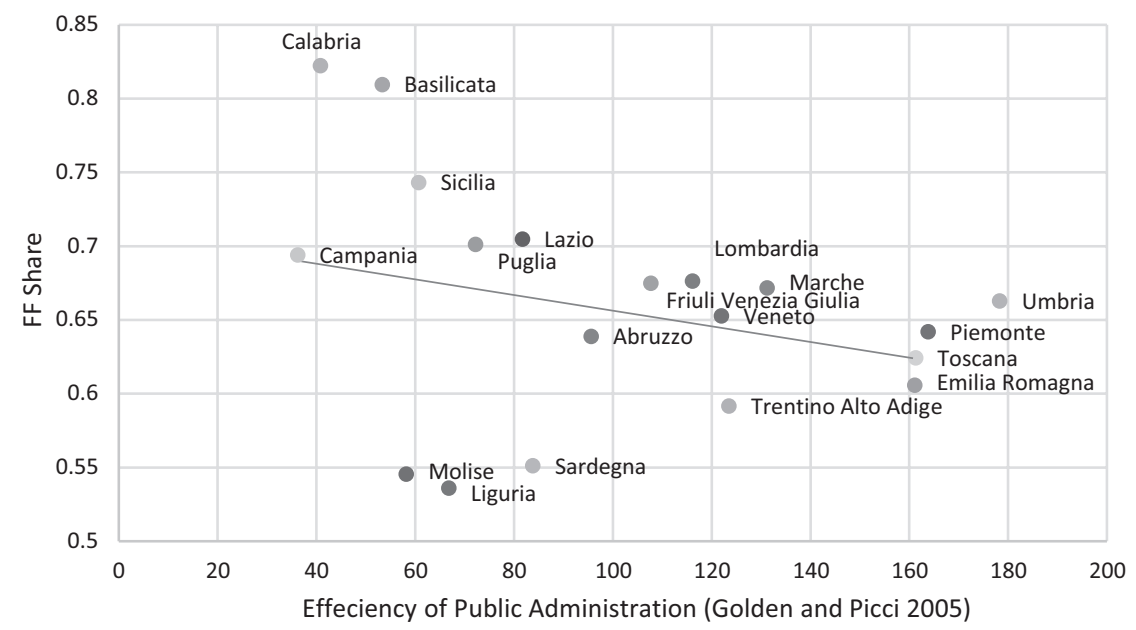

Figure 2.10 Quality of Italian regional institutions and share of family firms. Note: $y=0.7191-0.00058 x(p$-value $=0.169)$.

index was created in 1997 by focusing on the difference between the total amount of financial resources allocated to build infrastructure in regions and the physical inventory of public capital that has effectively been built after controlling for regional differences in the cost of public construction. The intuition underlying this indicator is that, all else being equal, if the difference between these measures is large, that means the focal government is not getting the infrastructure it has paid for due to the presence of corruption (Golden \& Picci, 2005). The indicator is based on the ratio between the aforementioned two measures and is expressed as ratio to the national average. A higher value implies lower corruption and therefore higher-quality regional institutions.

Even though it is not significant, Figure 2.10 shows a preliminary pattern indicating that the prevalence of family firms decreases with the efficiency of public administration, supporting the arguments that family firms are better equipped to survive in less developed formal institutional contexts. Even though this theory has been used to explain the presence of family firms in emerging economies, it looks like it can also be applied to developed economies by considering the different stages of regional development.

\section{Family firms and regional competitiveness across Italian regions}

\section{Regional productivity, regional exports, and regional innovation}

To explore the possible relation between the prevalence of family firms and regional competitiveness, we use three aggregate regional measures: labour productivity, exports, and innovation. ${ }^{14}$ First, there is no evidence that the 


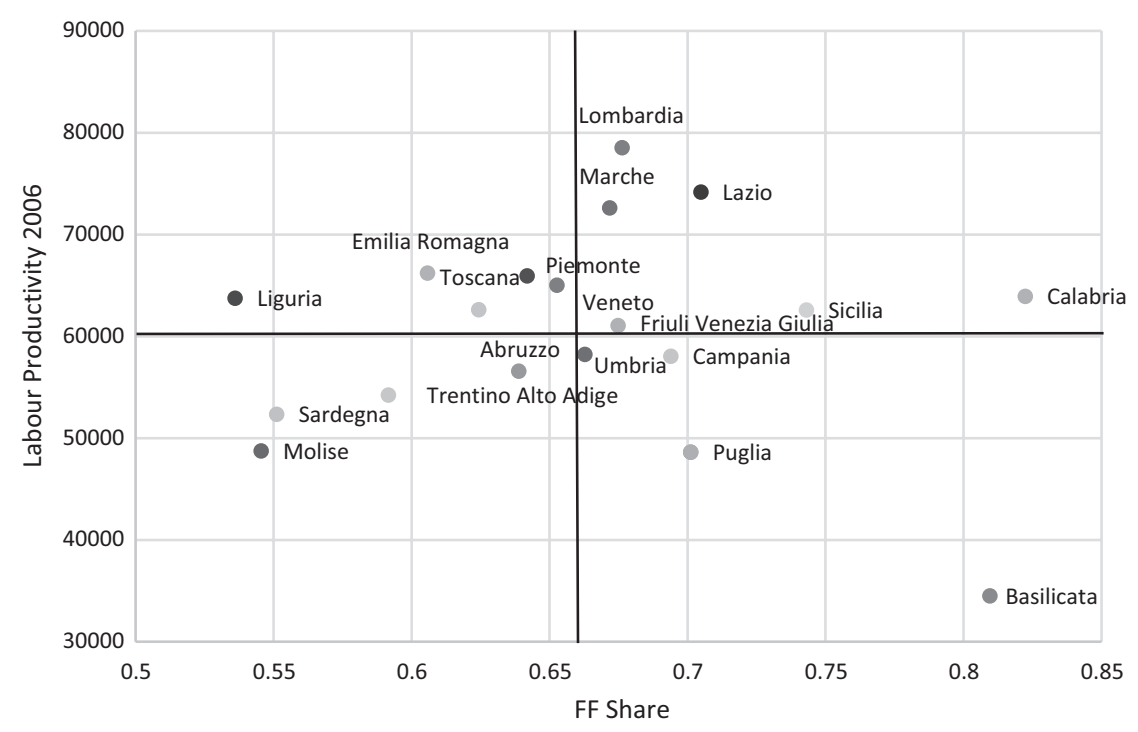

Figure 2.11 Share of family firms and labour productivity across Italian regions. Note: $y=65,473.45-7,685.174 x(p$-value $=0.809)$.

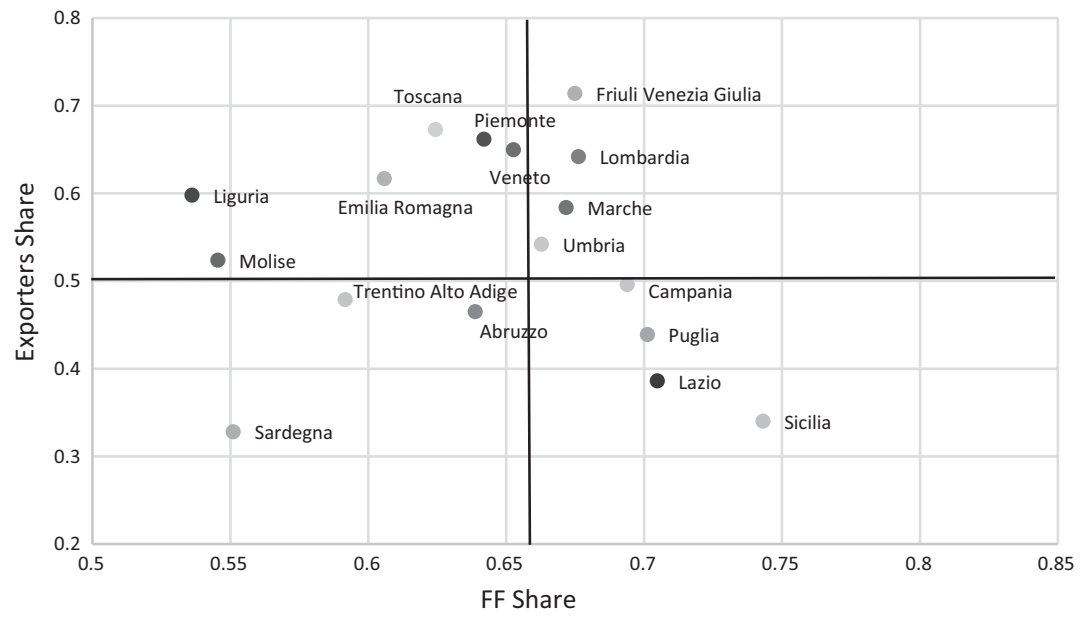

Figure 2.12 Share of family firms and regional exports across Italian regions. Note: $y=1.246-1.13 x(p$-value $=0.013)$.

prevalence of family firms is positively or negatively related to regional labour productivity (Figure 2.11). When analysing regional exports, there is preliminary evidence that the relationship is negative. However, there is a group of regions (Friuli Venezia Giulia, Lombardia, Marche, and Umbria) characterised by a high presence of family firms and a high share of exporters 


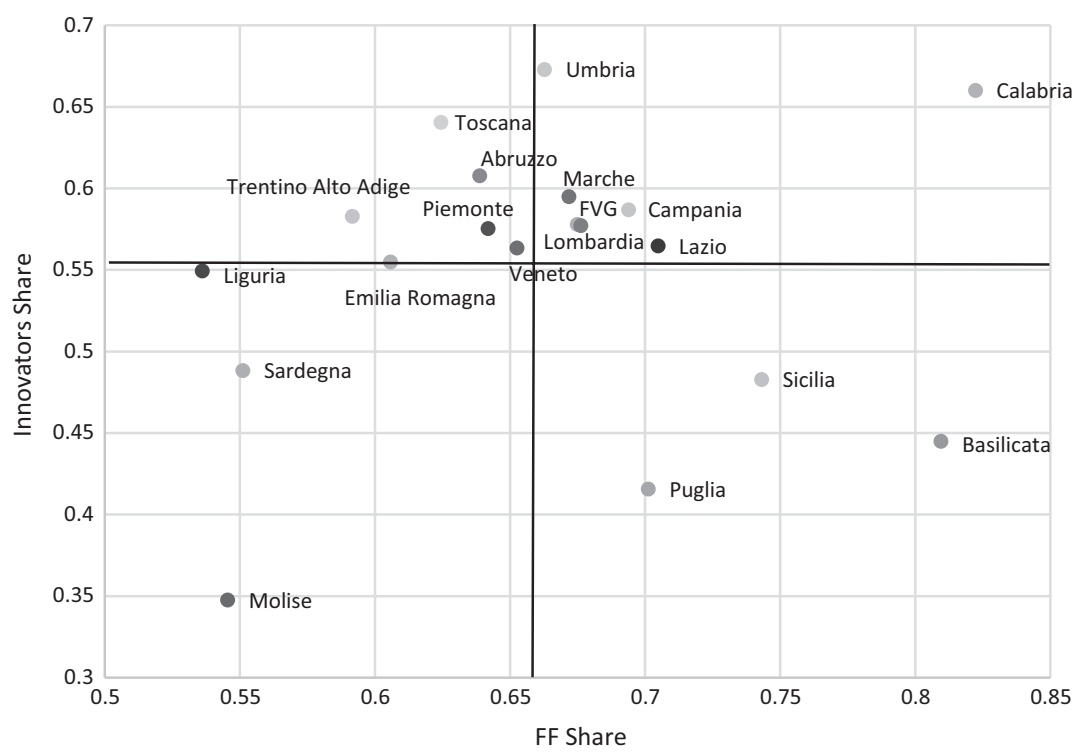

Figure 2.13 Share of family firms and regional innovation across Italian regions. Note: $y=0.45+0.15 x(p$-value $=0.552)$.

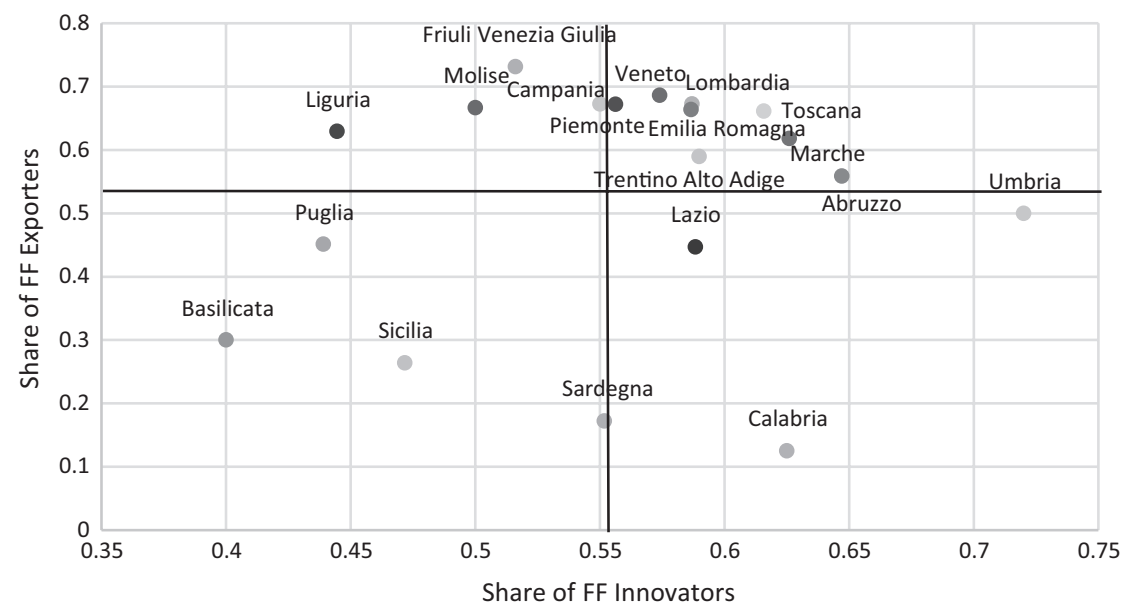

Figure 2.14 Share of family firm innovators and family firm exporters across Italian regions.

(Figure 2.12). Finally, the share of regional innovators does not seem to have a relationship with the regional prevalence of family firms (Figure 2.13). In line with findings from Stough et al. (2015), our results show the need to further investigate the aggregate effect of family firms on regional competitiveness to uncover their contributions to regional development. 
Finally, to explore the possible combination of family firm exporters and family firm innovators across regions, Figure 2.14 shows the position of Italian regions in four quadrants combining the share of regional family firm exporters and the share of regional family firm innovators. ${ }^{15}$ It seems that in some Italian regions, there is an interesting combination of a high level of family firm exporters and a high level of family firm innovators. These regions are positioned in the 'dynamic' quadrant.

\section{Conclusion}

The aim of this chapter was to present a descriptive picture of the phenomenon of family firms across European regions and to analyse its prevalence, its relationship with context, and its consequences for regional competitiveness. Our main conclusion is that the phenomenon of family firms is unevenly distributed across regions. Additionally, our intention was to dig into the relationship between family firms and regional context to provide some empirical evidence of the two-way relationship between family firms and regions - that is, the extent to which the territory determines the existence of family firms and the extent to which family firms contribute to regional

Table 2.12 Future research questions

\begin{tabular}{|c|c|}
\hline Research streams & Research questions \\
\hline $\begin{array}{l}\text { Share of family } \\
\text { firms across } \\
\text { industries }\end{array}$ & $\begin{array}{l}\text { Why does the presence of family firms vary across industries } \\
\text { and across industries and regions? } \\
\text { Is there any sector that favours/attracts family firms? } \\
\text { How do regional competitive advantages in certain industries } \\
\text { attract or repel the creation, retention, and survival of } \\
\text { family firms? } \\
\text { What are the competitive advantages that family firms are } \\
\text { able to developed to be overrepresented in some industrial } \\
\text { sectors? }\end{array}$ \\
\hline $\begin{array}{l}\text { Share of family } \\
\text { firms based } \\
\text { on business } \\
\text { and family } \\
\text { demographics }\end{array}$ & $\begin{array}{l}\text { Why is the presence of family firms unevenly distributed by } \\
\text { firm size, firm age, and familiness characteristics? } \\
\text { Do territorial conditions affect the size of firms and their life } \\
\text { span? } \\
\text { Why is the presence of family firms higher in the mature and } \\
\text { old firm categories instead of the young firm category? } \\
\text { Why do familiness characteristics vary across regions? }\end{array}$ \\
\hline $\begin{array}{l}\text { Share of family } \\
\text { firms and } \\
\text { regional } \\
\text { characteristics }\end{array}$ & $\begin{array}{l}\text { Is the prevalence of family firms in regions related to any } \\
\text { specific type of external agglomeration? } \\
\text { How does the formal (and informal) institutional context } \\
\text { affect the presence of family firms? } \\
\text { What combinations of formal institutional dimensions favour } \\
\text { or hinder the presence of family firms in regions? }\end{array}$ \\
\hline $\begin{array}{l}\text { Share of family } \\
\text { firms and the } \\
\text { effect on regional } \\
\text { competitiveness }\end{array}$ & $\begin{array}{l}\text { Do family firms contribute to regional competitiveness } \\
\text { (regional productivity, regional exports, and regional } \\
\text { innovation), and if so, where and how? }\end{array}$ \\
\hline
\end{tabular}


competitiveness. Instead of providing definitive answers, this book chapter has raised several research questions that future research should investigate further (see Table 2.12 for a summary of the most important research questions).

\section{Appendix A}

\begin{tabular}{|c|c|c|c|c|c|}
\hline \multicolumn{3}{|c|}{ UniCredit-Capitalia sample: 2006} & \multicolumn{3}{|c|}{ ISTAT census data: 2001} \\
\hline Regions & $\begin{array}{l}\text { Number } \\
\text { of firms }\end{array}$ & $\%$ & Regions & $\begin{array}{l}\text { Number } \\
\text { of firms }\end{array}$ & $\%$ \\
\hline Emilia Romagna & 578 & 12.0 & Emilia-Romagna & 10,718 & 11.3 \\
\hline $\begin{array}{l}\text { Friuli Venezia } \\
\text { Giulia }\end{array}$ & 140 & 2.9 & $\begin{array}{l}\text { Friuli-Venezia } \\
\text { Giulia }\end{array}$ & 2,582 & 2.7 \\
\hline $\begin{array}{l}\text { Trentino Alto } \\
\text { Adige }\end{array}$ & 66 & 1.4 & $\begin{array}{l}\text { Trentino-Alto } \\
\text { Adige }\end{array}$ & 1,247 & 1.3 \\
\hline Veneto & 610 & 12.7 & Veneto & 14,485 & 15.2 \\
\hline Northeast & 1,394 & 29.0 & Northeast & 29,032 & 30.6 \\
\hline Liguria & 50 & 1.0 & Liguria & 1,211 & 1.3 \\
\hline Lombardia & 1,533 & 31.9 & Lombardia & 24,513 & 25.8 \\
\hline Piemonte & 490 & 10.2 & Piemonte & 8,434 & 8.9 \\
\hline Valle D'Aosta & 6 & 0.1 & Valle d'Aosta & 88 & 0.1 \\
\hline Northwest & 2,079 & 43.2 & Northwest & 34,246 & 36.0 \\
\hline Lazio & 121 & 2.5 & Lazio & 2,811 & 3.0 \\
\hline Marche & 194 & 4.0 & Marche & 4,732 & 5.0 \\
\hline Toscana & 387 & 8.0 & Toscana & 8,680 & 9.1 \\
\hline Umbria & 77 & 1.6 & Umbria & 1,576 & 1.7 \\
\hline Centre & 779 & 16.2 & Centre & 17,799 & 18.7 \\
\hline Abruzzo & 108 & 2.2 & Abruzzo & 1,963 & 2.1 \\
\hline Basilicata & 12 & 0.2 & Basilicata & 415 & 0.4 \\
\hline Calabria & 29 & 0.6 & Calabria & 676 & 0.7 \\
\hline Campania & 152 & 3.2 & Campania & 4,065 & 4.3 \\
\hline Molise & 11 & 0.2 & Molise & 308 & 0.3 \\
\hline Puglia & 119 & 2.5 & Puglia & 3,718 & 3.9 \\
\hline Sardegna & 55 & 1.1 & Sardegna & 898 & 0.9 \\
\hline Sicilia & 70 & 1.5 & Sicilia & 1,897 & 2.0 \\
\hline South & 556 & 11.6 & South & 13,940 & 14.7 \\
\hline Total & 4,808 & 100 & Total & 95,017 & 100 \\
\hline
\end{tabular}

\section{Notes}

1 NACE-CLIO refers to the General Industrial Classification of Economic Activities in the European Communities (Nomenclature générale des Activités économiques dans les Communautés Européennes). NUTS stands for 'nomenclature of territorial unit for statistics' and represents European Union statistical regions. For more information, see http://ec.europa.eu/eurostat/web/nuts/ overview.

2 Given their relevance in national economies, large firms were oversampled. Since the sample design overrepresents large firms, researchers constructed sampling weights in terms of size-sector cells to make the sample representative of the underlying population (see Altomonte \& Aquilante, 2012). All the analyses in this chapter consider these weights. 
3 Given the representativeness of the EFIGE database, we are confident that the distribution of family firms in our dataset reflects the distribution in each country.

4 To preserve anonymity, the EFIGE database contains a randomised regional identifier for each country but not the name of the region (Altomonte \& Aquilante, 2012).

5 In all the figures in this chapter, horizontal and vertical lines identify the average value of the variables on the $y$ - and $x$-axes of the considered regions, respectively.

6 TFP was calculated for 2008 by the researchers involved in the EFIGE project and was made available by Bruegel. TFP was estimated by applying the Levinsohn and Petrin (2003) approach and by considering sectoral production functions. The estimates also control for country and year fixed effects over the 2001-2009 period. To estimate TFP, the EFIGE survey was matched with the Amadeus archive. However, the matching procedure involved a lot of missing values for TFP due to missing data in Amadeus (for more information, see Altomonte \& Aquilante, 2012).

7 A firm is considered to be an exporter if it was declared a direct exporter in 2008 or had been actively exporting prior to 2008. The share of regional exporters is calculated as the number of exporting firms among the total firms in a region.

8 Information on innovation comes from the firms' answers to specific questions on whether they introduced a product/process innovation during the survey period. The share of regional innovators is calculated as the number of innovative firms among the total firms in a region.

9 For each region, the share of family firms that are exporters (innovators) is calculated considering the number of family firms that were declared to be an exporter (innovator) out of the total number of family firms.

10 In the figure, the horizontal reference line identifies the average share of family firm exporters out of the 55 European regions, while the vertical line represents the average share of family firm innovators. The figure divides regions into four groups. The first group, in the first quadrant (bottom left), includes less dynamic regions characterised by a below-average share of both family firm innovators and exporters. In the second group, the second quadrant (top left), are regions with a high share of family firm exporters. The third group (top right) includes the most dynamic regions characterised by a high share of family firm innovators and exporters. The last group (bottom right) includes innovative regions with an above-average share of family firms that innovate.

11 The original Capitalia-Unicredit data encompassed 5,100 firms. After cleaning the data and excluding firms that did not answer the question used to classify firms as family firms, the number was reduced to 4,808 .

12 In Appendix A, we compare the distribution of our sample by region with data provided by the Italian National Institute of Statistics (ISTAT). As can be seen, the distributions are very similar. Northern firms are slightly over-represented in the sample, especially firms located in Lombardy, while the opposite holds for firms located in southern regions.

13 Too few firms are in the sample for Valle d'Aosta, so we excluded this region from all the tables (except Table 2.5) and figures.

14 Labour productivity is defined as value added over employment and refers to 2006. A firm is considered an exporter if it answered yes to the question 'Has the enterprise sold abroad some or all of its products in 2006?' A firm is considered an innovator if it introduced a product and/or process innovation in the 2004-2006 period. Regional values are calculated by aggregating firm values by region.

15 For information about definitions, see Notes 8, 9, and 10. 


\section{References}

Adjei, E. K., Eriksson, R. H., Lindgren, U., \& Holm, E. (2019). Familial relationships and firm performance: The impact of entrepreneurial family relationships. Entrepreneurship \& Regional Development, 31(5-6), 357-377.

Altomonte, C., \& Aquilante, T. (2012). The EU-EFIGE/Bruegel-Unicredit Dataset. Retrieved from www.efige.org.

Amatori, Franco and Bugamelli, Matteo and Colli, Andrea, Italian Firms in History: Size, Technology and Entrepreneurship (October 25, 2011). Bank of Italy Economic History Working Paper No. 13, Available at SSRN: https://ssrn.com/ abstract=2236737 or http://dx.doi.org/10.2139/ssrn. 2236737 .

Arrighetti, A., \& Ninni, A. (2012). German and Italian manufacturing performances: A premise to a comparison. Economia e Politica Industriale, 39(2), 5-16.

Astrachan, J. H., \& Shanker, M. (2003). Family businesses ' contribution to the U.S. economy: A closer look. Family Business Review, 16(3), 211-219.

Basco, R. (2015). Family business and regional development: A theoretical model of regional familiness. Journal of Family Business Strategy, 6(4), 259-271.

Basco, R. (2018). Family business in emerging markets. In R. Grosse \& K. E. Meyer (Eds.), The Oxford Handbook of Management in Emerging Markets (pp. 527-546). Oxford: Oxford University Press.

Basco, R., \& Bartkeviciute, I. (2016). Is there any room for family business into European Union 2020 Strategy? Family business and regional public policy. Local Economy, 31(6), 709-732.

Basco, R., \& Suwala, L. (2020). Spatial familiness - A bridge between family business and economic geography. In A. Calabrò (Ed.), A Research Agenda for Family Business: A Way Ahead for the field. Edward Edgar, forthcoming.

Berghoff, H. (2006). The end of family business? The Mittelstand and German capitalism in transition, 1949-2000. Business History Review, 80(2), 263-295.

Bjuggren, C. M., Johansson, D., \& Sjögren, H. (2011). A note on employment and gross domestic product in Swedish family-owned businesses: A descriptive analysis. Family Business Review, 24(4), 362-371.

BMWi. (2013). German Mittelstand: Engine of the German economy. Facts and Figures about Small and Medium-Sized German Firms. Berlin: Federal Ministry of Economics and Technology.

Burkart, M., Panunzi, F., \& Shleifer, A. (2003). Family firms. The Journal of Finance, 58(5), 2167-2201.

Chandler, A. D. (1990). Scale and scope: The dynamics of industrial capitalism. Cambridge, MA: Harvard University Press.

Chang, E. P. C., Chrisman, J. J., Chua, J. H., \& Kellermanns, F. W. (2008). Regional economy as a determinant of the prevalence of family firms in the United States: A preliminary report. Entrepreneurship Theory and Practice, 32(3), 559-573.

Charron, N., Dijkstra, L., \& Lapuente, V. (2014). Regional governance matters: Quality of government within European Union member states. Regional Studies, 48(1), 68-90.

Cucculelli, M., \& Micucci, G. (2008). Family succession and firm performance: Evidence from Italian family firms. Journal of Corporate Finance, 14(1), 17-31.

Faccio, M., \& Lang, L. H. P. (2002). The ultimate ownership of Western European corporations. Journal of Financial Economics, 65(3), 365-395. 
Golden, M. A., \& Picci, L. (2005). Proposal for a new measure of corruption, illustrated with Italian data. Economics \& Politics, 17(1), 37-75.

Gomez-Mejia, L. R., Basco, R., Müller, C., \& Gonzalez, A. C. (2020). Family business and local development in Iberoamerica. Cross-Cultural Management Journal, 27(2), 121-136.

Iuzzolino, G., Pellegrini, G., \& Viesti, G. (2011). Convergence among Italian regions, 1861-2011. SSRN Electronic Journal. Bank of Italy Economic History Working Paper No. 22. https://doi.org/10.2139/ssrn.2239019.

James, A. E., Hadjielias, E., Guerrero, M., Discua Cruz, A., \& Basco, R. (2020). Entrepreneurial families in business across generations, context, and cultures. Journal of Family Business Management, forthcoming.

Khanna, T., \& Palepu, K. (2000). Is group affiliation profitable in emerging markets? An analysis of diversified Indian business groups. Journal of Finance, 55(2), 867-891.

La Porta, R., Lopez-De-Silanes, F., \& Shleifer, A. (1999). Corporate ownership around the world. The Journal of Finance, 54(2), 471-517.

Levinsohn, J., \& Petrin, A. (2003). Estimating production functions using inputs to control for unobservables. The Review of Economic Studies, 70(2), 317-341.

Martinez-Garcia, I., Boubakri, N., Gomez-Anson, S., \& Basco, R. (2020). Ownership concentration in the Gulf Cooperation Council. International Journal of Emerging Markets, forthcoming.

Morck, R. \& Yeung, B. (2004). Family control and the rent-seeking society. Entrepreneurship Theory and Practice, 28(4), 391-410. https://doi.org/10.2139/ssrn.577802.

Pongelli, C., Calabrò, A., \& Basco, R. (2018). Family firms' international makeor-buy decisions: Captive offshoring, offshore outsourcing, and the role of home region focus. Journal of Business Research, 103, 596-606.

Stough, R., Welter, F., Block, J., Wennberg, K., \& Basco, R. (2015). Family business and regional science: "Bridging the gap." Journal of Family Business Strategy, 6(4), 208-218. 